\title{
IAMJ
}

INTERNATIONAL

AYURVEDIC

MEDICAL JOURNAL

\section{SUCCESSFULLY TREATED CASE OF GALAGANDA (HYPOTHYROIDISM) WITH THE HELP OF HERBOMINERAL COMPOUND - A CASE STUDY}

\author{
Shilpa Dhawale ${ }^{1}$, Vaibhav Dhawale ${ }^{2}$, Bhushan Raghuwanshi ${ }^{3}$ \\ ${ }^{1}$ Associate Professor, Department of Shalakya Tantra, Jupiter Ayurved Mahavidyalaya, Nagpur, Maharashtra, \\ India \\ ${ }^{2}$ Consultant, Shivmalhar Ayurvedic Clinic, Amravati, Maharashtra, India \\ ${ }^{3}$ Assistant Professor, Department of Kayachikitsa, DRGACH\&RC, Amravati, Maharashtra, India
}

Corresponding Author: bhushanraghuwanshi8@gmail.com

\section{https://doi.org/10.46607/iamj2409032021}

(Published online: March 2021)

Open Access

(C) International Ayurvedic Medical Journal, India 2021

Article Received: 16/02/2021 - Peer Reviewed: 28/02/2021 - Accepted for Publication: 04/03/2021

(D) Check for updates

\section{ABSTRACT}

Thyroid problems are among the most common endocrine disorders presently seen worldwide. Hypothyroidism results when the thyroid gland fails to produce enough of the thyroid hormone, due to structural or functional impairment that significantly impairs its output of hormones, this leads to the hypo metabolic state of hypothyroidism. According to Charaka presentation of multiple Granthi around the neck is called Gandmala and single swelling on the Parshava of the neck is Galganda. So Galganda can be co-related with hypothyroidism. The root cause of hypothyroidism is disequilibrium of tridosha. This is an effort to find out better treatment of Galagand by successfully treated case of Galagand with help of hypothetical herbomineral compound.

Keywords: Galaganda, Hypothyroidism, Shoth, etc

\section{INTRODUCTION}

Ayurveda- the Great Healer Science of ancient as well as modern era, maintained its relationship with the
Nature \& survived long period of 5000 years, making itself the oldest medical science of present world. The 
unique principles of Ayurveda based on HumanNature relationship. In this system (Ayurveda), each and every matter of this world is known to have some pharmacological action. In this world, one can't find even a single substance which is devoid of pharmacological action and can be used for the benefit of living organism on the basis of their properties. The great power of observations exactly resembles in Brihatrayis and Laghutrayis which gives information with detailed explanation about various concepts like Dincharya, Ritucharya, Rasayana and many more. Ayurvedic texts, although are silent about the wide knowledge of the disorder, yet several mini references are found scattered in various texts. There is no direct description of thyroid gland or their diseases in Ayurveda, but a disease named as Galagand mentioned under 20 sleshma vikaras by Acharya Charaka.(1) Acharya Sushruta described Galaganda as two encapsulated small or big swellings in neck which is placed in the sixth layer i.e. Rohini out of seven skin layers mentioned in Sharir sthana.(2) The analysis of the symptomatology of hypothyroidism in the light of Ayurvedic principle of Dosha and Dushya showed that in this disease the vitiation of Vata-Kapha and Dushti of Rasadhatu and Medadhatu are the main pathological agents. Looking at its chronicity and its effect on various body systems, there is need of a careful search to find out an effective and safe remedy against this soul- harrowing monster. Hence this successfully treated case study may rule out future possibilities of use Herbomineral Yoga (combination) in Galaganda w.s.r.to Hypothyroidism.

\section{Case Report}

The present case study is successful Ayurvedic management of Galaganda (Hypothyroidism). A 38-yearold female patient came to SHIVMALHAR Ayurvedic Clinic who presenting with the clinical criteria of Galganda (hypothyroidism) with pathological changes in thyroid profile tests in hypothyroidism i.e.T3, T4, TSH for 2 years was selected for the study.

\section{History of Present Illness}

The patient was having normal before 2 years. But then patient was gradually got symptomatic appearance of Galganda and diagnosed during routine pathological check-up. Patient was also psychological upset since last few years due to fear of complications. For which he took many oral medications. But there was not any significant relief. Hence, he came to SHIVMALHAR Ayurvedic Clinic for better management.

Past History: Not significant

\section{Personal History}

Name- xyz; Addiction- Tea; Age- 38 years, Bowel habit- Regular; Sex- Female; Appetite- Poor Marital status-Married; Sleep-Inadequate

Occupation-Teacher

Table 1: Ashtavidh Pariksha

\begin{tabular}{|l|l|}
\hline Nadi $($ Pulse) & $70 / \mathrm{min}$ \\
\hline Mala (Stool) & Saam \\
\hline Mutra (Urine) & Niram \\
\hline Jivha (Tongue) & Saam \\
\hline Shabda (Speech) & Aspashth \\
\hline Sparsha (Touch) & Sheet \\
\hline Drika (Eye) & Pallor+ \\
\hline Akriti (Built) & Madhyam \\
\hline
\end{tabular}

Table 2: Other

\begin{tabular}{|l|l|}
\hline BP & $120 / 90 \mathrm{mmhg}$ \\
\hline Bala & Madhyam \\
\hline Prakriti & Pitta-Kaphaj \\
\hline Height & $162 \mathrm{~cm}$ \\
\hline Weight & $67.5 \mathrm{~kg}$ \\
\hline
\end{tabular}


Table 3: Assessment Grade for Subjective \& Objective Criteria trial Drugs Herb mineral Compound - (Hypothetical combination)

\begin{tabular}{|c|c|c|c|c|c|}
\hline \multirow{2}{*}{$\begin{array}{l}\text { Sr. } \\
\text { No. }\end{array}$} & \multirow{2}{*}{ Parameter } & \multicolumn{4}{|l|}{ Gradation } \\
\hline & & 0 & 1 & 2 & 3 \\
\hline \multicolumn{6}{|c|}{ Subjective Criteria } \\
\hline 1 & $\begin{array}{l}\text { Nibaddha } \\
\text { Shwayathu (Neck } \\
\text { Swelling) }\end{array}$ & No swelling & $\begin{array}{l}\text { Mild swelling (Pal- } \\
\text { pable but not visible) }\end{array}$ & $\begin{array}{l}\text { Moderate swelling (Palpable } \\
\text { and Visible) }\end{array}$ & $\begin{array}{l}\text { Severe /Huge swell- } \\
\text { ing (Enlarged Thy- } \\
\text { roid gland) }\end{array}$ \\
\hline 2 & $\begin{array}{l}\text { Rasa-Aasyata } \\
\text { (changes in taste) }\end{array}$ & $\begin{array}{l}\text { No changes } \\
\text { in Rasa- } \\
\text { Aasyata }\end{array}$ & $\begin{array}{l}\text { Snigdhasyata (only } \\
\text { coated tongue) }\end{array}$ & $\begin{array}{l}\text { Madhuryamasyata (Taste sense } \\
\text { changes toward sweetness) }\end{array}$ & $\begin{array}{l}\text { Vairasyamasyata } \\
\text { (tastelessness) }\end{array}$ \\
\hline 3 & $\begin{array}{l}\text { Varna Parivartan } \\
\text { (changes in col- } \\
\text { our) }\end{array}$ & $\begin{array}{l}\text { No changes } \\
\text { in colour }\end{array}$ & $\begin{array}{l}\text { Mild discolouration } \\
\text { over affected site }\end{array}$ & $\begin{array}{l}\text { Moderate visible colour chang- } \\
\text { es towards Shya- } \\
\text { va/Aruna/Pandu }\end{array}$ & $\begin{array}{l}\text { Complete change of } \\
\text { colour of affected site }\end{array}$ \\
\hline 4 & $\begin{array}{l}\text { Gala-Talu Pari- } \\
\text { vartan (Throat } \\
\text { and neck chang- } \\
\text { es) }\end{array}$ & No changes & $\begin{array}{l}\text { Mild difficulty like } \\
\text { dysphagia }\end{array}$ & $\begin{array}{l}\text { Moderate difficulty like Talu- } \\
\text { gala prashosh (sore throat), } \\
\text { Jantogaleanushabdam (slurred } \\
\text { speech) }\end{array}$ & $\begin{array}{l}\text { Severe difficulty like } \\
\text { severe Dysphagia, } \\
\text { Aphagia }\end{array}$ \\
\hline 5 & $\begin{array}{l}\text { Ruja(pain at site } \\
\text { of swelling) }\end{array}$ & No pain & $\begin{array}{l}\text { Only Kndu (itching) } \\
\text { but no Ruja (pain) }\end{array}$ & $\begin{array}{l}\text { Kandu (Itching) with Moderate } \\
\text { or tolerable Ruja (pain) }\end{array}$ & $\begin{array}{l}\text { severe Kandu (Itch- } \\
\text { ing) and Severe pain } \\
\text { (Ruja) both }\end{array}$ \\
\hline 6 & Weight gain & BMI $<20$ & BMI 20-25 & BMI 25-30 & BMI 30-35 \\
\hline 7 & Muscle cramps & Not present & Once in a week & Twice / Thrice a week & Continuously present \\
\hline 8 & Dry\& coarse skin & No dryness & $\begin{array}{l}\text { Dryness after bath } \\
\text { only }\end{array}$ & $\begin{array}{l}\text { Dryness for whole day but re- } \\
\text { lieved by oil application }\end{array}$ & $\begin{array}{l}\text { Dryness not even } \\
\text { relieved by oil appli- } \\
\text { cation }\end{array}$ \\
\hline 9 & Fatigue & No fatigue & Mild fatigue & Moderate fatigue & Severe fatigue \\
\hline \multicolumn{6}{|c|}{ Objective Criteria } \\
\hline 1 & TSH level & $\begin{array}{ll}0.30- & 6.00 \\
\mathrm{IU} / \mathrm{ml} & \end{array}$ & $6.00-7.00 \mathrm{IU} / \mathrm{ml}$ & $7.00-8.00 \mathrm{IU} / \mathrm{ml}$ & $>8.00 \mathrm{IU} / \mathrm{ml}$ \\
\hline
\end{tabular}

The Samprapti of Hypothyroidism may include Doshas like Kapha - Vaat, Dushya like Meda - Dhatu and Agni hence we need to combine more herbs probably acting for Samprapti-Bhanga. The combination of Herbominaral Compound has drugs as fallows-

2. Jalakumbhi Bhasma,

3. Aparajita mula Churna

4. Punarnava Churna,

5. Vanga Bhasma

1. Navaka Guggulu

6. Gomutra as a Bhavana Dravya

Table 4: Composition of Herbomineral Compound

\begin{tabular}{|l|l|l|l|}
\hline Dravya (Drug) & Dose & Dravya (Drug) & Dose \\
\hline Amalaki & $26 \mathrm{mg}$ & Chiktraka & $26 \mathrm{mg}$ \\
\hline Haritaki & $26 \mathrm{mg}$ & Aparajita Mul Churna & $60 \mathrm{mg}$ \\
\hline Bibhitaki & $26 \mathrm{mg}$ & Punarnava Churna & $60 \mathrm{mg}$ \\
\hline Sunthi & $26 \mathrm{mg}$ & Vanga Bhasma & $60 \mathrm{mg}$ \\
\hline Marich & $26 \mathrm{mg}$ & Jalakumbhi Bhasma & $60 \mathrm{mg}$ \\
\hline Pippali & $26 \mathrm{mg}$ & Shudhha Guggulu & $26 \mathrm{mg}$ \\
\hline Musta & $26 \mathrm{mg}$ & Gomutra & 1 lit \\
\hline Vidanga & $26 \mathrm{mg}$ & Total & $500 \mathrm{mg}$ \\
\hline
\end{tabular}


Table 5: Intervention Chart:

\begin{tabular}{|l|l|l|}
\hline Drug & Anupana & Duration \& Dose \\
\hline Herbomineral compound & Warm Water & $\begin{array}{l}2 \text { Tab }-500 \mathrm{mg} \text { each Morning \& Evening } \\
30 \text { days }\end{array}$ \\
\hline
\end{tabular}

Results: The progress will be noted on the basis of assessment parameters, parametric test before treatment $\&$ after treatment.

Table 6:

\begin{tabular}{|l|l|l|l|}
\hline Sr. No. & Assessment Parameters & Before Treatment & After Treatment \\
\hline 1 & Nibaddha Shwayathu (Neck Swelling) & 2 & 1 \\
\hline 2 & Rasa-Aasyata (changes in taste) & 1 & 0 \\
\hline 3 & Varna Parivartan (changes in colour) & 1 & 1 \\
\hline 4 & Gala-Talu Parivartan (Throat and neck changes) & 2 & 0 \\
\hline 5 & Ruja (pain at site of swelling) & 2 & 1 \\
\hline 6 & Weight gain & 1 & 0 \\
\hline 7 & Muscle cramps & 1 & 0 \\
\hline 8 & Dry \& coarse skin & 2 & 1 \\
\hline 9 & Fatigue & 2 & 1 \\
\hline 10 & TSH Level & 2 & 1 \\
\hline
\end{tabular}

\section{DISCUSSION}

Above mentioned Herbomineral compound is formed by combining three herbs (Jalakumbhi, Aparajita and Punarnava) with one mineral (Vanga Bhasma) along with Navak Guggulu. The Navaka Guggulu consists of 10 (with Shuddha Guggulu) drugs and similar to the Medohara Guggulu in contents. Navaka Guggulu is mentioned in Medorogadhikar. All combination has Deepan - Pachan as well as Lekhan Guna. It is mentioned by Bhaishajya Ratnavali (Prakarana 39/43) (3) \& Chakradutta (4). Jalakumbhi is the drug mentioned in Galaganada Chikitsa by various Acharyas. It is also rich in Iodine content hence this herb plays major role in Hypothyroidism because one of the causes of Hypothyroidism is Iodine deficiency. Jalakumbhi has Madhur- Kashaya rasa and Laghu- Ruksha Guna which act as Lekhniya as well as it has Tridoshagna properties (5). Aparajita has katu-Tikta-Kashaya Rasa with Laghu Ruksha Guna along with Ushna Virya helps to maintain Tridoshagna property. It also has Medhya Karma which tends to minimise the stress factor and minimises cortisol level. Aparajita also act as Vishaghna and Chakshushya (6). Punarnava is best Shothahar and diuretic in nature. It has TiktaKashaya-Katu-Madhur Rasa with Laghu Ruksha Guna and Ushna Virya Helps for Kapha - Vaatahar karma which are the major etiological factor for Galaganada. Gomuta is also has karma of Kapha Vaathar in nature. It also does Lekhan karma by its Rasa-Guna-Virya and Vipaka. With the help of Amla Rasa it promotes Agni Deepan function. All of above drugs together works as Kapha - vaathara, Lekhana, Medhya, Medohara as well as Agni-Deepak which breaks down the Samprapti of Galaganda.

\section{CONCLUSION}

The concept of Galaganda disease explained in text is a part of Sthanik Shoth due to Meda Dhatu Dusthi influenced with vitiation of Vaata and Kapha. Samprapti of Hypothyroidism is directly related with Agni (Jatharagni and Dhatwagni) also involves Strotovaigunya of Medovaha Strotas and vitiation of Vata and Kapha primarily, if untreated then interact with other DhatuAgni due to extreme vitiation of Vata, Kapha and Meda. All the selected symptoms derived from Galaganada (Hypothyroidism), got relief significantly due to Tridoshaghna especially Kapha-Vaatshamak, Medoghna, Dhatvagni-Deepak, Strotorodhanashak, Galagangahar, Sukshma strotogami and Rasayana property of Herbomineral Compound. 


\section{SCOPE FOR STUDY}

There is a need of study by using this formulation on a large-scale sample and on various entities for more accuracy, because present trial work is carried out on a single patient.

\section{REFERENCES}

1. Agnivesha, Charaka, Dridhabala, Charaka Samhita, Sutra-sthana, Maharoga Adhyaya, 20/17, edited by Dr. Brahmanand tripathi, Chaukhamba surbharati prakashana Varanasi, reprint 2008, pg. 395.

2. Sushruta, Sushruta Samhita, Shareera sthana, Garbhavyakarana sharira Adhyaya, 4/4, edited by kaviraaj Ambikadutta shastri, Chaukhamba Sanskrit sansthan Varanasi, reprint 2010, pg. 37.

3. Mishra B, Vaishya R, editors. Bhavaprakasha of Shri Bhavamishra, Purva Khanda, $11^{\text {th }}$ ed. Vol 1. Ver. 42. Varanasi: Chaukhambha Sanskrit Bhavana; 2010. P.205

4. Dwivedi R, editor. Chakradatta of Acharya Chakrapanidatta, sthaulya Chikitsa. Reprint. Ch. 36, Ver.18 Varanasi: Chaukhambha Sanskrit Bhavana; 2011. P.222

5. Ibidem, Vrindamadhava or Siddha Yoga (19), Galagandadhya adhikara, 41/8, pg. 412.

6. Ibidem, Vrindamadhava or Siddha Yoga (19), Galagandadhya adhikara, 41/3, pg. 412.

\section{Source of Support: Nil}

\section{Conflict of Interest: None Declared}

How to cite this URL: Shilpa Dhawale et al: Successfully Treated Case Of Galaganda (Hypothyroidism) With The Help Of Herbomineral Compound - A Case Study. International Ayurvedic Medical Journal \{online\} 2021 \{cited March, 2021\} Available from: http://www.iamj.in/posts/images/upload/663 667.pdf 